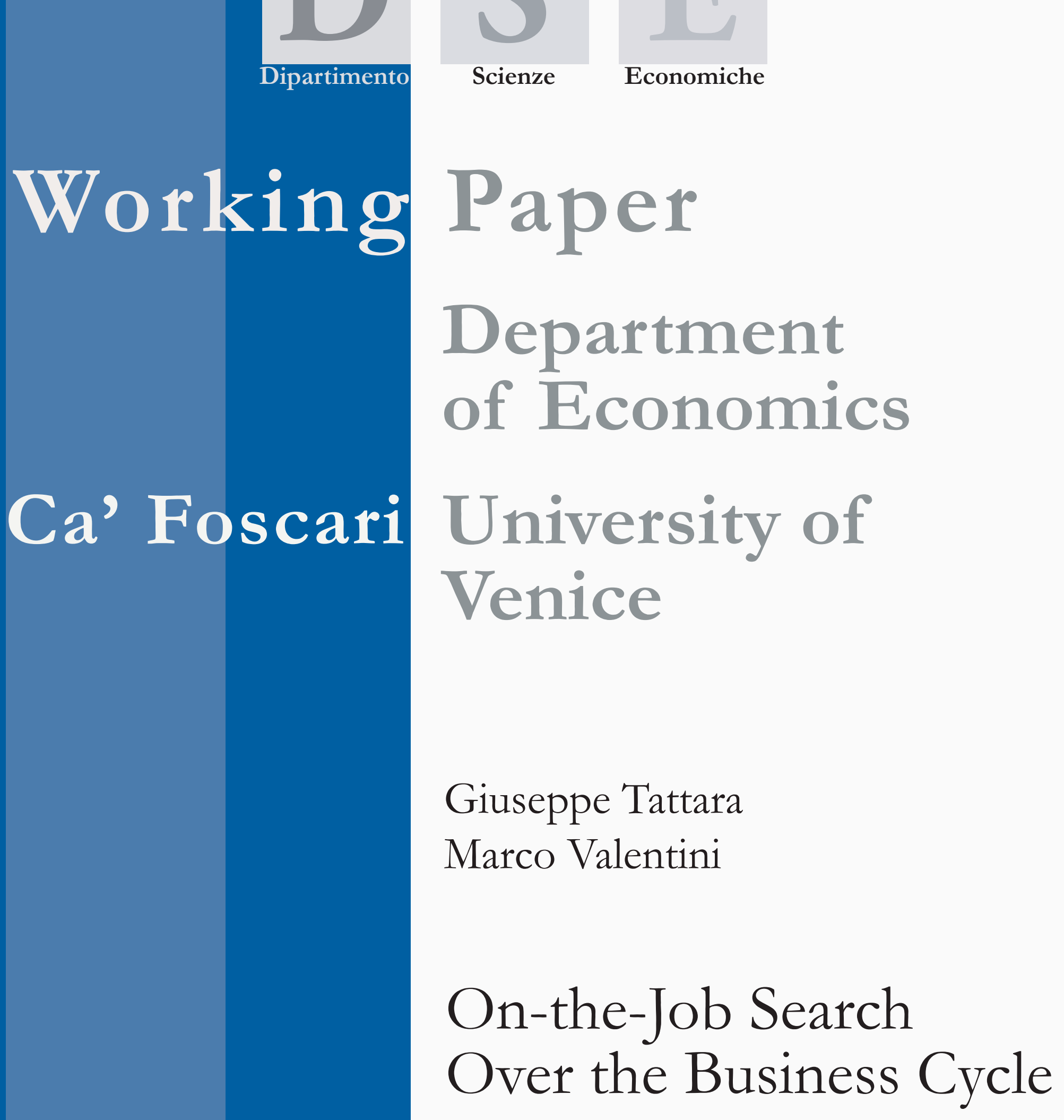




\title{
On-the-Job Search Over the Business Cycle
}

\author{
Giuseppe Tattara and Marco Valentini \\ Department of Economics \\ Universita' di Venezia
}

\begin{abstract}
On-the-Job Search is one of the most common and efficient ways to look for a new job: most of the time workers move directly from one employment position to another (E-to-E) without an intervening spell of unemployment. E-to-E transitions are a relevant component of total labour flows and have a definite cyclical pattern.

This paper computes E-to-E worker flows through the development of a vacancy chain model. An iterative procedure is used to compute the successive reallocation runs, beginning from an autonomous vacancy and then to reconstruct the complete E-to-E transition process. The procedure is implemented and applied to a large micro-panel based on a highly industrialized Italian region from 1982 to 1996.

E-to-E transitions are an increasingly large portion of worker flows in the labour market. They are clearly cyclic and the number of transitions increases over time as the labour market becomes tighter. These are the flows that explain labour market dynamics in upswings and recessions. Search models that look only at flows between employment, unemployment and outside of the labour force underestimate labour mobility and its cyclical pattern.
\end{abstract}

Keywords: Job Flows; Search and Matching; Job to Job Mobility; Worker Flows; Business Cycle; Propagation

JEL Codes: E24; E32; J63

Address for correspondence:
Giuseppe Tattara
Department of Economics
Ca' Foscari University of Venice
Cannaregio 873, Fondamenta S.Giobbe
30121 Venezia - Italy
Phone: $(++39) 0412349148$
Fax: $(++39) 0412349176$
e-mail: tattara@unive.it

This Working Paper is published under the auspices of the Department of Economics of the Ca' Foscari University of Venice. Opinions expressed herein are those of the authors and not those of the Department. The Working Paper series is designed to divulge preliminary or incomplete work, circulated to favour discussion and comments. Citation of this paper should consider its provisional character.

$\begin{aligned} \begin{array}{r}\text { The Working Paper Series } \\ \text { is availble only on line }\end{array} & \begin{array}{l}\text { Department of Economics } \\ \text { Ca' Foscari University of Venice }\end{array} \\ \text { (www.dse.unive.it/pubblicazioni) } & \text { Cannaregio 873, Fondamenta San Giobbe } \\ \text { For editorial correspondence, please contact: } & \text { 30121 Venice Italy } \\ \text { wp.dse@unive.it } & \text { Fax: ++39041 2349210 }\end{aligned}$




\section{On-the-Job Search Over the Business Cycle ${ }^{1}$.}

This paper explores the magnitude of employment to employment (E-to-E) flows in a group of firms. Workers differ greatly in their set of skills, capabilities and expectations and jobs differ greatly in the diligence and skills they require from workers. Worker flows are surprisingly high in all phases of the business cycle and worker inflows and outflows are observed contemporaneously within the same productive unit ${ }^{2}$. The fact that gross flows are much higher than net flows implies a great deal of heterogeneity among the firms, jobs and workers.

Worker flows are quantitatively relevant in the Veneto labour market: over the 1982-1996 period an average of 1/5 of total employees changed status each year, moving to a new situation. These workers moved to a new job, to unemployment or out of the labour force altogether. However, studies that look only at flows between these three states grossly underestimate the extent of worker mobility. Gross flows are due to many different elements: the growth and decline of firms is one of them, but the most important element is the never-ending search process which both firms and workers engage in. Little is known about the movement of workers from one job to another, but a large proportion of job flows is the result of employees seeking an alternative position, which results in job switches that involve no significant spell of unemployment. E-to-E flows in Veneto - a territory that is rich with small firms and that has a high level of employment - are significant: they account on average for $35 \%$ of total yearly gross worker flows (associations + separations) and involve $17 \%$ of the annual stock of employees (Tattara and Valentini, 2005).

We compute a simple model of labour turnover from a longitudinal micro data panel, which has a rich set of implications for the discussion about labour market behaviour. The computation of job switches is based on the vacancy chain model. E-to-E flows are strictly defined on the basis of the replacement process that follows a quit or a firing: this definition is based on the early work by Akerloff, Rose and Yellen (1988) and by Contini and Revelli (1988), but adopts a more general framework, corrects some previous inconsistencies and computes E-to-E flows

${ }^{1}$ This research is part of the Miur project 1999-2001, n. 9913193479 and 2002-2003, n. 2001134473. We thank Bruno Contini, Francis Kramartz, and the people who participated in EALE 2004, AIEL 2005 and the Prin MIUR 2005 conference for their comments and suggestions. We are responsible for any mistakes.

${ }^{2}$ The unit of analysis is the unit that pays social security for its employees. In the case of firms with several establishments - that meet some specified requirements - each establishment is entitled to pay social security contributions for their employees directly. A firm using a decentralized payment system can always 'centralize' social security payments within a single unit. Due to this ambiguity we use the word 'establishment' and avoid the word firm, when referring to the subject of social security contributions.

The problems inherent to evaluating the effects of the fiscal bonus - D.L. 30 December 1979 , n. 663 - are linked to the firms declaring their irregular employees to social security for the first time, and as a consequence, the large break in the series over 1980-1981. For this reason we did not consider the earlier years, 1975-1981, and limited our research to the 1982-1997 period. 
within the respective vacancy chain model for a period of 14 years, making it possible to study the job search process over two economic cycles. This new way of looking at the labour market helps to explain the amplification process that characterises the volatility of vacancies over the business cycle and provides a plausible explanation of the cyclical behaviour of separations, a puzzle for much economic literature according to Ackerlof et al. (1988).

Recently, several economists have called attention to the importance of E-to-E flows, but their analyses have been mainly theoretical and we know of no study trying to compute the vacancy chain process from empirical data. Our results provide an interesting challenge to the conclusions advanced by recent theoretical literature (Nagypál, 2004; Krause and Lubik, 2004; Nagypál, 2005a; 2005b; Shimer, 2003;2005)

The article is organized as follows. The first paragraph briefly describes the data and the framework used to present our results. The second discusses the relation between workers and job flows. The following paragraph computes the vacancy chain model, exploiting the VWH (Veneto Worker Histories) longitudinal panel and points to the main empirical results. Our data generate more amplification that one would have expected from the standard search models. The importance of the magnitude and cyclicality of the E-to-E transitions during two economic cycles, the characteristics of the workers and jobs involved and the implications of our empirical results for labour market modelling are discussed in paragraphs 4 and 5 . Our conclusions are presented in the last paragraph. The difference between churning or excess reallocation flows computed as the difference between gross flows and job flows, and the vacancy chain computation of E-to-E flows is presented and discussed in the appendix.

\section{Data.}

Recent works on job and worker flows exploit matched employer-worker data to examine whether workers' engagements and separations are related with the creation and destruction of jobs by employers. Studies cover various countries and sectors from the late seventies up to the present day. Some studies rely on a quarterly frequency and some on an annual frequency (Abowd and Kramartz, 1999; Bingley and Westergard-Nielsen, 2000; Burgess, Lane and Stevens, 2000; 2001; Heisz and Picot, 2001; Leonard and von Audrenrode, 1999).

The ideal dataset for analysing the divergence between job and worker flows is based on the universe of employers matched by the universe of workers, because the definition of job flows is based on employer behaviour over time. The longitudinal panel we work with, Veneto Workers Histories (VWH), is built from the administrative records of the Italian Social Security System (Inps). It refers to the total population of employers and employees in two provinces - Treviso and Vicenza - of a North-eastern Italian region, the Veneto. Everyone employed in this territory in the private sector (state and local government employees are excluded, with a few exceptions), from 1982 to 1997, is included, except for those who are self-employed, farm workers and people who receive no salary.

VWH data provide register-based information about all establishments located in Treviso and Vicenza and about the employees that have been hired by those establishments for one day or more during the period of observation, independently of the workers' place of residence. The longitudinal panel is based on monthly 
histories of the working life of each employee built on the archive unit of observation, the employer-day.

A 'cleaned' social security archive was used. The engagements/separations and the creations/destructions that are due to a change in the juridical nature of the employer and not matched by a corresponding change of the working population assessed at the establishment level were defined as 'spurious' and were thus deleted. This led to a $7 \%$ reduction in total engagements and separations in the manufacturing sector. Similarly, if there are short breaks in the employment spell, as long as the worker continues with the same employer, the spell was considered to be uninterrupted. ${ }^{3}$ The complex matching procedure is explained in Occari and Pitingaro (1997).

Data include all individual employment spells with an employer, for whatever duration ${ }^{4}$. All sizes of establishments are considered because the study area is characterized by a multitude of very small units: the average plant size in 1996 was less than 15 employees and it would appear improper to skip the smaller plants.

The longitudinal panel has records on establishment and worker flows from 1982 to 1997, a rather long period of time, compared with other studies of this kind; employers are classified in the three-digit sector classification, ATECO 1981. ${ }^{5}$ The long observation period allows us to discuss the role of resignations, recruitment and turnover in relation to two expansionary cycles which took place in two distinct periods: 1984 - 1990 and 1993 - 1996.

\section{Job and worker reallocation.}

Worker flows are defined as the number of engagements and separations in the time interval in relation to a job. Engagements measure new appointments, separations measure terminated contracts, i.e. resignations and layoffs. Both measures are defined in continuous time ${ }^{6}$. Total engagements can be thought of as the sum of three types of flows: employment to employment, unemployment to employment and from outside the labour force to employment. Separations can be thought of as these same flows moving in the opposite direction.

One of the causes of a position opening is, of course, the ongoing process of economic change, which results in the destruction of some jobs, causing the permanent involuntary layoff of those employees, coupled with the simultaneous creation of new jobs. In every industrial sector firms create and destroy jobs. Changes in jobs are influenced by economic growth, the business cycle, structural change and competition between industries. Job flows are certainly a large part of worker flows, they contribute to their magnitude and cyclical behaviour but by no means are equal or proportional to worker flows (Boeri, 1996; Davis and

\footnotetext{
${ }^{3}$ This is common practice when working with social security data, see Bingley and Westergård-Nielsen (2002).

${ }^{4}$ In a related work (Tattara and Valentini, 2003) we demonstrated that although average jobs are characterized by short spells, they are concentrated among young workers. The average worker's current experience is characterized by long spells.

${ }^{5}$ Revelli (1995) and Rapiti (1998). On the Inps data base used in the present paper, see Tattara and Volpe (2001, 18-22).

${ }^{6} \mathrm{~A}$ job is a position filled by a worker and refers, generally, to an establishment. Social security contributions can be paid by the firm or, in case of a firm with more than one permanent establishment, by the establishment. The firm may centralize social security payments nonetheless.
} 
Haltiwanger, 1996; Leonard and von Audenrode 1999; Tattara and Valentini, 2005). Our empirical results show that countercyclical job destruction (jobs are destroyed in recession) does not lead to the same cyclicality in worker flows, as separations do not increase in recession (see also Nagypal, 2004).

\section{Employment-to-employment episodes.}

We compute E-to-E flows through the vacancy chain model, a way to reconstruct the employment to employment transition process through all its successive steps. This provides a very clear interpretation of the process, and provides a more precise measure, particularly when the aim is to discuss to what extent the findings about cyclicality of job flows extend to the cyclicality of worker flows and if countercyclical job destruction involves countercyclical worker separations.

3.1. The vacancy chain model. A large number of job matches in modern labour markets are transitions from other jobs. A vacancy opens up any time entrepreneurs revise their matching in an attempt to improve the productive assortment of their employees and any time workers leave their job in search of a better one.

Any reallocation activity, to replace a person who has resigned or has been laidoff, may create a secondary wave of reallocations, which in turn may create a third wave and so on, ad infinitum. For example, a worker who quits his job to look for a better salary, or who retires, creates a job vacancy that provides an opportunity for another active worker to take the new position; this second resignation opens another vacancy and the chain continues as far as other employed workers reshuffle across the new set of job openings. A vacancy chain consists of a succession of E-toE switches that involve no intervening spell of unemployment and no leakages (new entrances or exits) ${ }^{7}$.

A vacancy chain is triggered by the creation of an autonomous vacancy. Once a vacancy opens up within a firm it may be filled by: 1. hiring a worker from the ranks of the employed, i.e. hiring from another firm; 2. hiring a worker from the pool of the non-employed, i.e. from the unemployed or from outside of the active labour force.

Hiring an employed person means: 1.1. hiring a worker from another firm who is filling an active position which creates a vacancy; or 1.2. hiring a worker from another firm who is redundant and is not replaced.

Hiring from the employed is likely to create a sequence of new vacancies. The expected length of such a sequence depends on the probability of hiring from each of the three pools of workers: the active labour force, redundant workers (i.e. active workers who are not going to be replaced) and active job seekers. Hiring a worker from outside the labour force or a redundant worker either sets up no chain or brings an end to the existing chain. ${ }^{8}$ Only hiring an active worker starts a positive chain and allows the chain to proceed to a successive step.

\footnotetext{
${ }^{7}$ New entrances and exits end the vacancy chain.

${ }^{8}$ Davis and Haltiwanger (1999, p.2758) argue that the traditional definition of churning neglects the second wave of workers following the first creation-destruction: "For example, a person who quits an old job in favour of a newly created job potentially creates a chain of further quits as other workers reshuffle across the new set of job openings. It follows that the direct plus indirect contribution of job flows to worker
} 
The length of the vacancy chain can be defined as the number of job switches that occur for each autonomous vacancy (Akerloff, Rose and Yellen, 1988).

The measure of E-to-E flows, as the set of the reallocation waves, connects the various reallocation episodes in a sequence, which begins with the creation of an autonomous vacancy or of an autonomous job opening: an increase in employment, a withdrawal of an active worker from the labour force, a retirement, a firing or a voluntary resignation in favour of unemployment.

In the following chart the horizontal arrows represent the mechanism of the vacancy chain. Diagonal arrows point to the leakages from the chain.

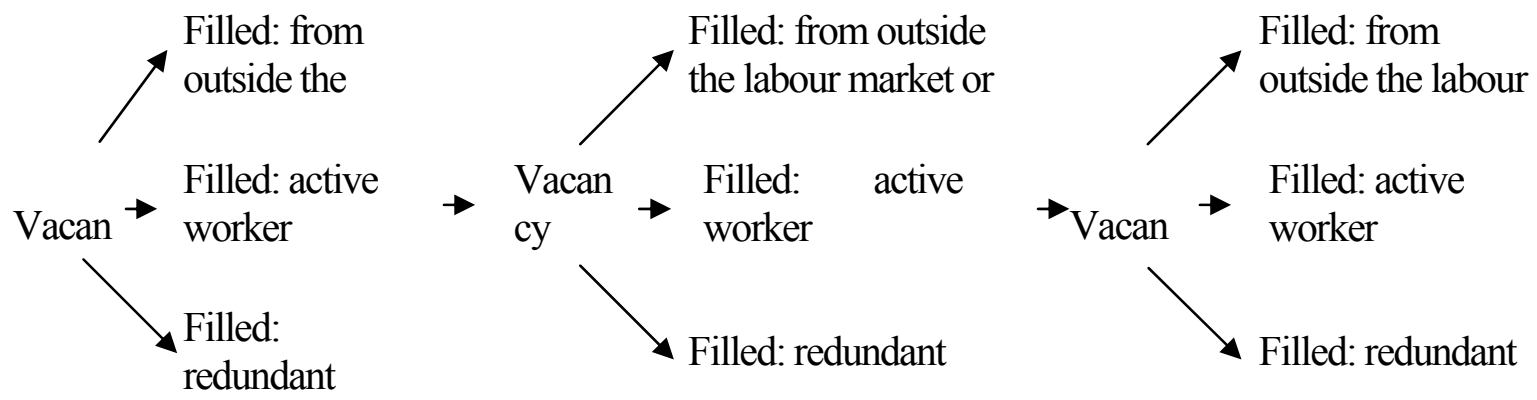

The probability of encountering a redundant position is a function of the entrepreneur's reaction to a vacancy, the value he attributes to the position, the availability of workers with the required skills, and their willingness to fill the slot.

3.2. The vacancy chain rounds. In order to calculate the vacancy chain an employerlevel database referring to the whole population is needed, so it is possible to take into account all the reallocation waves which follow from an initial autonomous vacancy or an autonomous job opening. Among E-to-E shifts, speedy reallocations from one manufacturing job to another are significant, and this is underlined by frequent claims from local entrepreneurs concerning the spread of labour poaching practices. E-to-E within manufacturing represents $50 \%$ of the total E-to-E switches shown in the data-base that includes all the private non-agricultural sectors.

E-to-E shifts are defined according to the length of the matching period. A long matching period makes the replacement process uncertain, since slow replacements are indistinguishable from flows coming from and going into unemployment: in empirical work quick re-hires are the most suitable data to represent E-to-E shifts. We assume that in order to register an E-to-E flow, the transfer process must be accomplished within 4 months.

The software, devised in order to compute the vacancy chain model, aims at reconstructing the single successive rings of the chain or the allocation waves in the labour market. The present analysis is limited to manufacturing.

The vacancy chain computational software is based on the following definitions:

\begin{tabular}{ll|l}
\hline Chain domain (labour market & The geographical boundaries are the two \\
\hline
\end{tabular}

reallocation exceeds the figures....". Not quite the point. TT-GJT - the usual churning definition - embeds all the worker waves, but the two ways of computing the churning magnitude, TT-GJT and E-to-E, are built on very different definitions of the reallocation process. See Appendix. 


\begin{tabular}{|c|c|}
\hline boundaries) & $\begin{array}{l}\text { provinces of Treviso and Vicenza and } \\
\text { the branch boundaries are } \\
\text { manufacturing (Ateco 1981,3 and 4). }\end{array}$ \\
\hline Active worker & $\begin{array}{l}\text { A previously employed worker (i.e. } \\
\text { separated for } 4 \text { months or less) in } \\
\text { manufacturing in Treviso or Vicenza, } \\
\text { replaced within } 4 \text { months. }\end{array}$ \\
\hline A new entrant & $\begin{array}{l}\text { A worker, who registered in the Inps } \\
\text { archive for the first time between 1982- } \\
1997 \text {. }\end{array}$ \\
\hline $\begin{array}{l}\text { Vacant position: a vacant position is } \\
\text { created when an existing contract is } \\
\text { terminated or when an employer wants } \\
\text { to hire an additional worker and draws } \\
\text { up a new contract. }\end{array}$ & $\begin{array}{l}\text { A separation followed by an association, } \\
\text { an association not preceded by a } \\
\text { separation. }\end{array}$ \\
\hline Beginning of the chain or chain seed & $\begin{array}{l}\text { A vacant position filled by an active } \\
\text { worker, not accompanied by a } \\
\text { separation by the same employer within } \\
\text { three months. }\end{array}$ \\
\hline Ring of the chain & $\begin{array}{l}\text { Filling of a vacancy by a worker within } \\
4 \text { months. }\end{array}$ \\
\hline Redundant position & $\begin{array}{l}\text { A quit or a layoff that does not lead to } \\
\text { replacement within } 4 \text { months. }\end{array}$ \\
\hline Worker from outside the labour force & $\begin{array}{l}\text { A worker who has no previous record in } \\
\text { the social security archives or who is } \\
\text { unemployed. An unemployed worker is } \\
\text { a worker, who has been registered the } \\
\text { Inps archive in the past, but has not been } \\
\text { employed for at least four months, after } \\
\text { the termination of the preceding } \\
\text { contract. }\end{array}$ \\
\hline Time & $\begin{array}{l}\text { The vacancy chain runs from twelve } \\
\text { months before to twelve months after } \\
\text { the year of reference. Almost all waves } \\
\text { exhaust within this time period. }\end{array}$ \\
\hline
\end{tabular}

Of course the tighter the boundaries, the shorter the chain, since leakages become more numerous. Leakages due to workers flowing out of the territorial borders are, on average, less than $2.5 \%$ of total quick hirings.

The replacement process has been computed under various binding conditions which were imposed upon E-to-E matching: blue collars must be substituted by blue collars, separations can be matched by engagements only if the salary of the engaged worker ranges within $\pm 30 \%$ from the salary of the separated worker, etc.... The computed bounded chains are a bit smaller than the unbounded chains. The two

${ }^{9}$ Contini and Revelli assume that the number of the initial vacancies is equal to creations. Our computational procedure is more general as vacant positions include quits and retirements as specified. 
procedures were tested and the difference never exceeded 5\%. At the end only the time of matching was considered (less or equal to four months). The number of rings that make a chain is limited to 10 , given that the $99,9 \%$ of the computed chains ends within 10 months. Any time a vacancy was followed by several contemporaneous hirings, one hiring was selected by considering the closest proximity between the vacancy and the hiring according to the previously mentioned variables, in the order they are presented.

The results of the computation process are summarized for the calendar year 1989 .

65.048 Total number of new contracts, registered in 1989, with workers from any place of origin, in manufacturing, in establishments in Treviso and Vicenza. ${ }^{10}$

29.934 Quick hires (re-employed in $\leq 4$ months) in manufacturing in establishments in Treviso and Vicenza, independent of previous employment.

35.114 Slow hires (18.327 workers re-employed in $\geq 4$ months) and new entrants in manufacturing in establishments in Treviso and Vicenza (16.787).

19.987 Quick hires (re-employed in $\leq 4$ months) of workers in manufacturing in establishments in Treviso and Vicenza who were already employed in manufacturing in Treviso and Vicenza. These are E-to-E reallocation flows. ${ }^{11}$

17.898 Hires tracked through the vacancy chain computation (about $90 \%$ of 19.987 , i.e. of quick hires).

21.135 Endogenous components of the chain or active reallocating workers. There are 7.654 vacancies which appear at the beginning of the chains, or chain seeds. There are 13.481 remaining multiplied components. ${ }^{12}$

2.026 Redundant workers

\footnotetext{
${ }^{10}$ Establishments that declare their employee contributions to the Inps. See footnote 3.

${ }^{11}$ There are 19.987 chain rings in 1989 , but our software identifies 21.135 rings, since some of the chains detected preceed 1989. There are 17.898 rings in the calendar year 1989 which is $90 \%$ of the total, and this is the coverage percentage reported in the last column of table 2 .

1221.135 is larger than 19.987 as the multiplier process extends over 1989.
} 
Table 2. Manufacturing in Treviso and Vicenza: The vacancy chain.

\begin{tabular}{|c|c|c|c|c|c|c|}
\hline year & $\begin{array}{c}\text { chain } \\
\text { seeds or } \\
\text { autonomo }\end{array}$ & $\begin{array}{c}\text { multiplie } \\
\mathrm{d} \\
\text { componen }\end{array}$ & multiplier & $\underset{\mathrm{S}}{\text { redundant }}$ & $\begin{array}{c}\text { chain } \\
\text { coverage }\end{array}$ & $\begin{array}{c}\text { E-to-E \% } \\
\text { quota of } \\
\text { engageme }\end{array}$ \\
\hline 1982 & 2902 & 3810 & 1,313 & 624 & 0,970 & 16.3 \\
\hline 1983 & 2328 & 2881 & 1,238 & 490 & 0,976 & 13.2 \\
\hline 1984 & 2905 & 3706 & 1,276 & 524 & 0,970 & 15.9 \\
\hline 1985 & 4120 & 5747 & 1,395 & 781 & 0,959 & 20.5 \\
\hline 1986 & 4718 & 6925 & 1,468 & 1036 & 0,951 & 23.6 \\
\hline 1987 & 5537 & 8426 & 1,522 & 1327 & 0,931 & 25.9 \\
\hline 1988 & 6825 & 11278 & 1,652 & 1686 & 0,895 & 30.9 \\
\hline 1989 & 7654 & 13481 & 1,761 & 2026 & 0,895 & 33.3 \\
\hline 1990 & 7325 & 12480 & 1,704 & 1950 & 0,908 & 30.6 \\
\hline 1991 & 5778 & 9223 & 1,596 & 1672 & 0,893 & 26.7 \\
\hline 1992 & 4972 & 7468 & 1,502 & 1533 & 0,924 & 23.2 \\
\hline 1993 & 3770 & 5304 & 1,407 & 1159 & 0,944 & 19.4 \\
\hline 1994 & 5719 & 9771 & 1,709 & 1397 & 0,866 & 27.1 \\
\hline 1995 & 7422 & 14595 & 1,966 & 1783 & 0,825 & 33.8 \\
\hline 1996 & 6276 & 11857 & 1,889 & 1614 & 0,831 & 29.2 \\
\hline $\begin{array}{c}\text { averag } \\
\mathrm{e}\end{array}$ & 5217 & 8463 & 1,560 & 1307 & 0,916 & 24,6 \\
\hline $\begin{array}{c}\text { St.de } \\
\text { V. }\end{array}$ & 1737,77 & 3749,29 & 0,22 & 514,56 & 0,05 & 6,50 \\
\hline
\end{tabular}

The chain computation has been truncated at the tenth slot, but the direct computation represents on average $92 \%$ of the total chain rounds, as in the previous example relating to 1986 . The last column of table 2 gives the incidence of the E-toE flow resulting from the vacancy chain computation on total engagements and separations, which is on average 25\%: 1 in every four labour contracts redrawn in this period can be "explained" by the need to act quickly to fill a job opening that was left vacant by a worker who went to take up a position at a different manufacturing firm. If we take the episode that triggered the chain into account as well, E-to-E quick hires are on average more than $35 \%$ of total engagements and separations (more than 1 in every three).

Blanchard and Diamond (1989) constructed E-to-E flow series for the United States and concluded that these movements account on average for $15 \%$ of total hires in the 1968-81 period. In the UK, the employment Audit gives rise to an estimate of E-to-E moves that, in 1992, were more than $50 \%$ of total hires, although according to quarterly labour data, the result overstates the importance of this component (Petrognolo and Pissarides, 2001). Pissarides (1994) speculates that Eto-E flows are probably not inferior to $40 \%$ of total hires, while Burda and Wyplosz (1994) estimated E-to-E flows for Germany and got a value of $16 \%$ of total hiring flows. Data from France point to a percentage similar to or lower than the German one. Schettkat, in his study of the German labour market, computes a percentage of total hirings at $16 \%$ and refers to values comparable to these as indicative of a tight labour market (Schettkat, 1996b). The Veneto data provide a very high value, which is more in line with Pissarides' expectations than with computations for other 
European countries. If the matching period is reduced to one month or less the E-toE average percentage of total hires declines to $23 \%$, which is still rather high in comparison with available figures for Germany and France.

\section{Properties of the vacancy chain.}

4.1. The growing importance of the E-to-E flows. The probability of hiring from the employed and from the unemployed depends on the tightness of the labour market. When unemployment is high, the number of job seekers who are unemployed or who are outside the active labour force is large relative to the number of employed job seekers. The probability of recruiting an unemployed person to any given vacancy, thus ending the chain, is high. In a tight labour market there are fewer unemployed or out-of-the-labour-force jobseekers than employed ones, and so fewer new entrants than employed people are hired, and vacancy chains are longer.

In the Veneto, the total number of E-to-E flows was 6000 in 1982 and it increased to 20.000 over 15 years, while in the same period the stock of manufacturing employees grew by around $25 \%$. The Veneto labour market was tighter at the end of the period because first entrances underwent a substantial loss, declining from $10 \%$ of the employment stock in the late seventies to $6 \%$ in the mid eighties and then to a low of $3 \%$ in 1993 . The entrance rate has subsequently recovered in part because of a positive contribution from non-EU workers, which brought the first entrances back up to $6 \%$ in the mid nineties. The retirement rate ${ }^{13}$ did not vary over the 15-year period, except for a visible increase in 1992 and 1995, in relation to two important reforms laws, Riforma Amato and Riforma Dini. The high rate of industrial growth achieved by the Veneto region since the seventies has led to an almost continuous reduction in the rate of unemployment through time.

4.2. The amplification mechanism, and the volatility of vacancies over the business cycle. Autonomous vacancies have increased through time and this is mainly the result of a larger number of small firms entering and exiting the economy as time goes by: the creation of new products, variety and diversification which have been representative of the Veneto's flexible system of production over the last few decades are often associated with firms' high turnover and a high number of job creations and destructions.

All together, however, creations and destructions represent only a small part of worker flows. The largest portion of worker flows is due to the fact that workers choose to search on-the-job and employers reap higher benefits from contacting employed searchers (Tobin, 1972). The multiplied component of the vacancy chain model represents the amplification mechanism that develops any time employers prefer to contact job seekers who are already employed. The probability that a newly encountered job seeker is employed rises in expansion, thereby making it more attractive for firms to post vacancies and this amplification helps to explain the volatility of vacancies during the business cycle.

Figure 2. Vacancy chain duration and unemployment percentage (left scale)

\footnotetext{
${ }^{13}$ Approximated by computing the number of separations involving workers over 50 years old.
} 


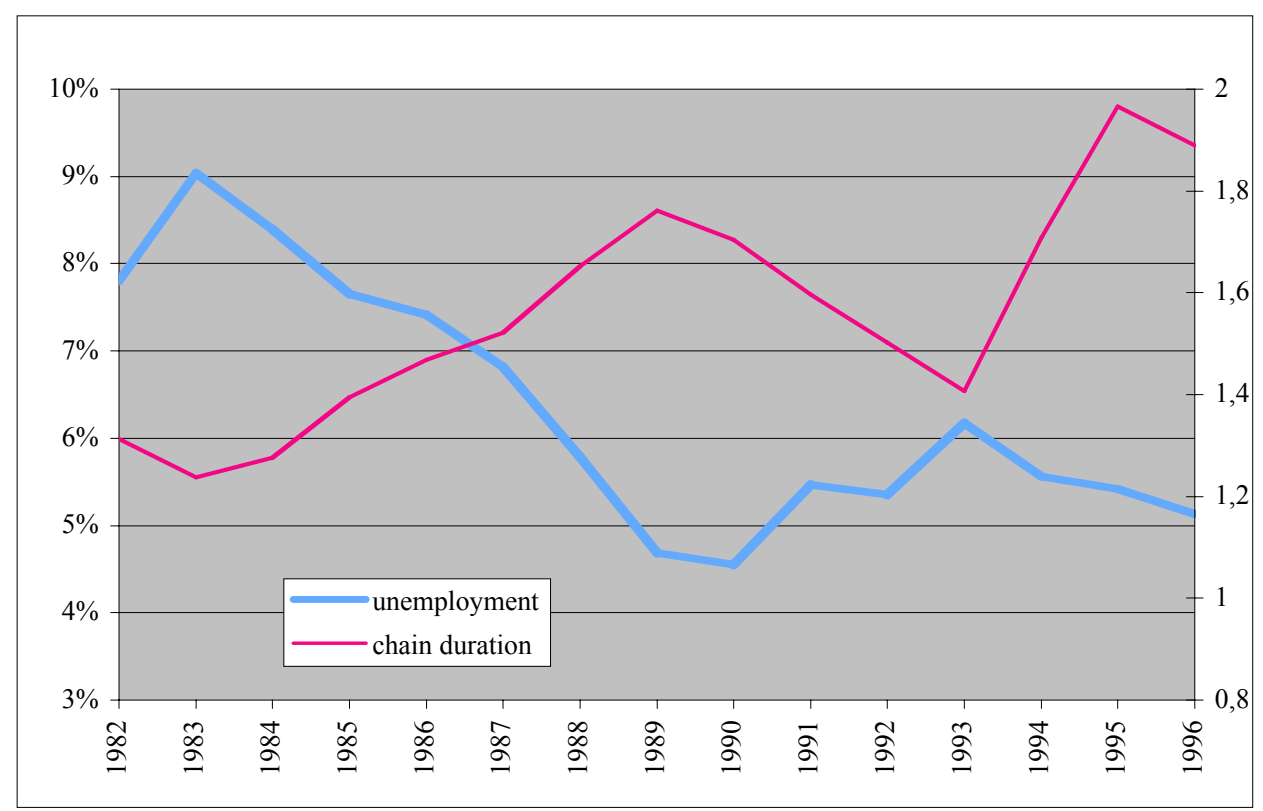

Unemployment figures were taken from Veneto Lavoro, various issues Chain duration is defined as the chain multiplied component

The multiplied component represents the length (number of rounds) of the vacancy chain in terms of vacancies-quick hiring, while redundant positions represent labour flows directed towards individuals who are outside the labour force or unemployed. Figure 2 shows the extent to which this amplification mechanism helps in explaining the volatility of vacancies over the business cycle and shows how unemployment and vacancies respond, in opposite ways, to the ups and downs during the cycle. The logic of the vacancy chain is capable of generating more amplification than the standard model and it explains why total separations, and especially E-to-E separations, are pro-cyclic, without making any reference to labour market regulations such as those implied by the Statuto dei Lavoratori (Workers' Statute) that imposes legal restrictions against firings and other protection measures. Separations increase as opportunities expand because E-to-E flows are the main component of total flows, and these flows, by definition, imply an equal number of hirings and separations.

4.3.The procyclicality of separations. The common view among labour economists is that high unemployment during recession is the result of the increasing rate at which workers separate from their employers. Contrary to that, empirical research has shown that separations decline in recession. According to Akerloff, Rose and Yellen (1988) and Shimer (2003) separations' procyclicality remains an occurrence that is not well explained by the contemporary economic literature (Nagipál, 2004).

Our data show that the fraction of workers separating from their employers is largely independent from the increase in unemployment experienced in the 1993 recession. In recession most of the increase in the incidence of unemployment is due instead to the declining rate at which, once separated, workers experience E-to-E transitions, with no intervening unemployment spell, as opposed to employment-to- 
unemployment transitions (Figure 3). E-to-E transition time can be computed from the individual employees by taking into account the interval between the employee separation and the successive hiring. In the period from 1990 to 1996, the percentage of very quick fillings (fillings $\leq 1$ month over total fillings) from the employee side follows the cycle, with a marked pattern. In downswing the interval between separation and the successive hiring tends to increase and workers, once separated, experience quick hiring at a declining rate. In upswings quick hirings are more frequent.

E-to-E timing can also be computed from the employer side, taking into account the time from the posted vacancy and the hiring for the single firm; the employer E-to-E timing is larger than the employee timing in upswing and lower in recession, a clear sign of the shift in power during the cycle.

Slow fillings, both from the employee and the employer side, manifest a declining trend since 1988, which shows that structural conditions in the labour market are now tighter than in the eighties. (table 3 ). ${ }^{14}$

Figure 3. Vacancy chain. Slow filling over total filling experienced by employees and by employers.

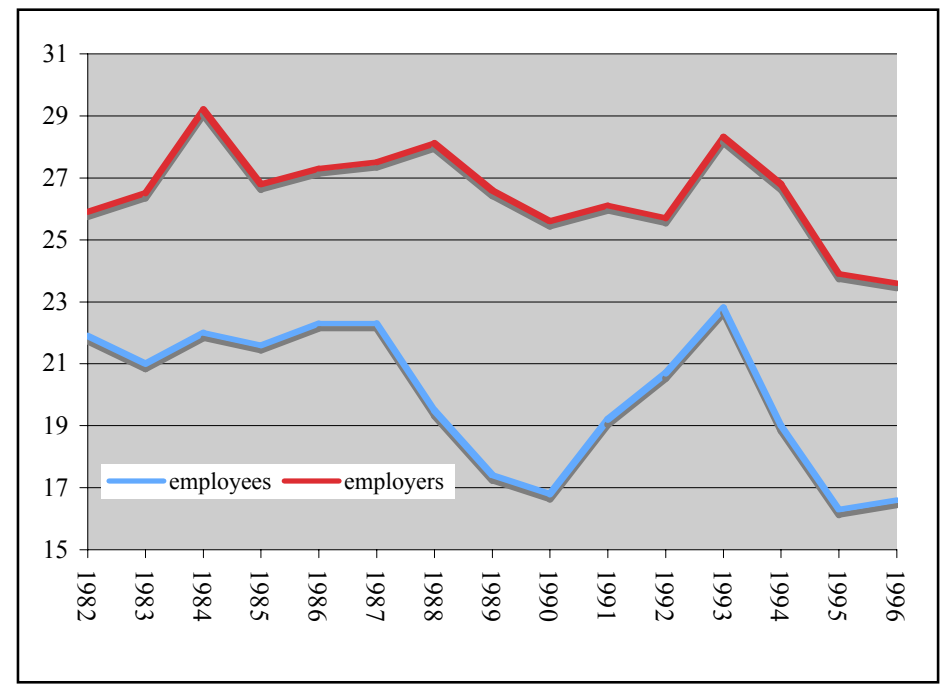

Chain seeds vary with the cycle, peaking in 1989 and in 1995 and having a low in 1983 and 1993. A decline in the rate of unemployment over the cycle in the early nineties (50\% from 1984 to 1991) is associated with a rise in the separation rate of a similar amount (51\%) and a double increase in the E-to-E flows: the elasticity is roughly 2 . The length of the vacancy chain, i.e. the multiplied component, is longer when unemployment is low. Viceversa, an increase in the rate of unemployment (1991-1994) is associated with a decline in the separation rate of a similar amount and a larger decline in E-to-E allocations.

\footnotetext{
${ }^{14}$ The underlining idea is the following: assume all workers quit and immediately find new jobs in different firms which have been trying to fill vacancies for some months. The intraemployment filling time is shorter from the workers' perspective than from the firms' perspective.
} 
In the time period considered - 1982-1996 - hirings and job creations are closely linked, with a correlation coefficient of 0.85 ; separations are significantly correlated with hirings, 0.52 , and insignificantly correlated with job destructions, 0.13 .

$\underline{\text { 5. Bad jobs, good jobs and worker heterogeneity. }}$

In upswing, job seeking by employed people expands the pool of potential hirees for firms, by adding to unemployed job seekers. On-the-job searching is measured by our dynamic empirical computation and is motivated in a straightforward manner by the presence of several types of jobs, which differ in terms of desirability and worker heterogeneity.

5.1.E-to-E flows vary with gender and age. Firms use employment status as a signal of quality and are more reluctant to hire unemployed applicants than employed ones. As the labour market becomes tight in upswing, E-to-E flows increase with respect to the number of unemployed that are hired and more qualified workers enter the vacancy chain. According to our calculations, males are more active in the reallocation process than females in upswing and towards the end of the period when labour market becomes tight: the ratio between the two first columns of table 3 increases in the late eighties and towards the end of the period. As a trend, young people definitively lose ground in favour of more mature workers: at the end of the period $35 \%$ of workers who were employed in the vacancy chain are more than 27 years of age, while in the early eighties this figure stayed below $20 \%$. This is the result of the tightening of the labour market, of two subsequent positive shocks, of the aging of the employee stock over time and of higher schooling as well (table 3 ).

Table 3. E-to-E flows by gender, age and re-employment speed.

\begin{tabular}{|l|c|c|c|c|c|c|c|c|}
\hline & \multicolumn{3}{|c|}{ gender/TR* } & \multicolumn{4}{c|}{ age/TR* } & \multicolumn{2}{c|}{$\begin{array}{l}\text { 2 time month }<4, \% \text { (slow } \\
\text { filling over total filling) }\end{array}$} \\
\cline { 2 - 9 } & Male & Female & $\leq 20$ & $20, \leq 27$ & $>27, \leq 3 \phi$ & $>36$ & employees & employers \\
\hline 1982 & 3,1 & 2,9 & 5,9 & 3,6 & 2,0 & 1,2 & 21,9 & 25,9 \\
\hline 1983 & 2,5 & 2,3 & 5,0 & 2,7 & 1,6 & 1,1 & 21,0 & 26,5 \\
\hline 1984 & 3,1 & 3,0 & 6,7 & 3,5 & 2,1 & 1,3 & 22,0 & 29,2 \\
\hline 1985 & 4,5 & 4,5 & 9,8 & 5,0 & 2,8 & 1,9 & 21,6 & 26,8 \\
\hline 1986 & 5,1 & 5,2 & 11,1 & 5,8 & 3,4 & 2,1 & 22,3 & 27,3 \\
\hline 1987 & 6,1 & 5,7 & 12,4 & 6,9 & 3,8 & 2,4 & 22,3 & 27,5 \\
\hline 1988 & 7,9 & 6,7 & 14,5 & 9,0 & 5,1 & 3,0 & 19,5 & 28,1 \\
\hline 1989 & 8,5 & 7,9 & 13,9 & 10,5 & 6,7 & 3,7 & 17,4 & 26,6 \\
\hline 1990 & 7,8 & 7,1 & 12,2 & 9,5 & 6,5 & 3,7 & 16,8 & 25,6 \\
\hline 1991 & 6,0 & 5,4 & 10,2 & 7,3 & 5,0 & 2,6 & 19,2 & 26,1 \\
\hline 1992 & 5,1 & 4,5 & 9,7 & 6,2 & 4,2 & 2,2 & 20,7 & 25,7 \\
\hline 1993 & 4,0 & 3,3 & 7,8 & 4,7 & 3,2 & 1,8 & 22,8 & 28,3 \\
\hline 1994 & 6, & 5,6 & 12,9 & 8,0 & 5,1 & 2,7 & 19,0 & 26,8 \\
\hline 1995 & 8,7 & 7,5 & 15,0 & 10,7 & 7,3 & 4,2 & 16,3 & 23,9 \\
\hline 1996 & 7,0 & 6,0 & 12,5 & 8,8 & 6,0 & 3,4 & 16,6 & 23,6 \\
\hline average & 5,7 & 5,2 & 10,6 & 6,8 & 4,3 & 2,5 & 20,0 & 26,5 \\
\hline St.dev. & 2,02 & 1,75 & 3,15 & 2,59 & 1,82 & 0,97 & 2,30 & 1,51 \\
\hline
\end{tabular}

$\mathrm{TR}=$ employees subject to the risk of separation within the year (stock thirings not counted in the stock) 
5.2. E-to-E flows reshuffle workers from bad to good jobs. When an employed worker switches sectors, the marginal revenue product of labour in the originating sector increases and this provides an incentive to the firms to create a new vacancy and replacement occurs. The worker is not replaced if a negative shock reduces the marginal revenue product of labour. Workers moving from employment in search of a new job start to find jobs in more productive sectors or good jobs in growing sectors, with high wages and favourable prospects. The low productivity sectors or bad jobs are jobs where replacement is scarce and redundant are numerous: hirings due to additional job openings are not able to attract employed workers and draw workers out of unemployment. Unemployed workers search for jobs and employed workers search for better jobs.

Table 4. Sectors involved in E-to-E flows.

\begin{tabular}{|l|l|}
\hline $\begin{array}{c}\text { Ranking: E-to-E flows over employee } \\
\text { stock }\end{array}$ & \multicolumn{1}{|c|}{ Dynamics through time } \\
\hline Machines and parts $(32+34)$ & Strong positive \\
\hline Leather $(44)$ & None \\
\hline Metal and mech.products $(31)$ & Positive \\
\hline Plastic (48) & Strong positive \\
\hline Furniture (46) & None \\
\hline Garments and shoes $(45)$ & Negative \\
\hline Paper and printing $(47)$ & Positive \\
\hline Textile $(43)$ & None \\
\hline
\end{tabular}

1981 Ateco classification in brackets

Sectors that total a lot of vacancies - the chain beginners - are active sectors or gaining sectors, and in our study area this role is played by general mechanics. Sectors that total few vacancies - the chain closers - are passive or losing sectors and the main passive sector is represented by garments and shoes, a sector that has suffered a marked decline in employment due to product delocalization into East Europe (Table 4). ${ }^{15}$

\section{Conclusions}

Modelling the dynamics of the labour market through the help of the vacancy chain during a long period of time has led us to discover relevant regularities, which are useful for labour market modelling. The study shows the prevalence and cyclicality of E-to-E transitions among worker flows. Studies looking at flows between the states of employment, unemployment and being outside of the labour force largely underestimate the extent of worker mobility in the labour market.

In addition, E-to-E flows must become an integral part of any model designed to explain business cycle variations in labour market

\footnotetext{
${ }^{15}$ The sector ranking is rather stable during the whole study period .
} 
modelling. Our data show that the chain multiplied component amplifies the business cycle in relation to labour flows. Firms hire from the employed in expansion and at the same time entrepreneurs post the newly created vacancies and in so doing they amplify the initial movement (autonomous vacancies) and this helps to explain the volatility of labour flows during the business cycle.

The fraction of workers separating from their employers is largely independent from the cycle. In recession most of the increase in the incidence of unemployment is due to the declining rate at which, once separated, workers experience rapid E-to-E transitions: the rate at which workers separate stays fairly constant during the cycle and the increase of unemployment in recession is due to the much bigger delay that workers, once separated, experience in transiting to a new job. The paper challenges the traditional view among macroeconomists studying aggregate labour markets that low unemployment during recessions are, to a large extent, due to rigidity in labour market legislation (i.e. workers protection against firing). Eto-E flows reduce in recessions and this explains the low separation number.

Of course worker and job heterogeneity play an active role in the system. During the last twenty years, in Veneto, there has been a limited shift in E-to-E distribution, extending mobility to more mature workers. The employee stock in manufacturing is now made up of less young workers and more mature workers than in the early eighties, because of changes in population structure. In 1996 E-to-E flows involved a larger number of employees in their thirties and the mobility of mature workers was more extensive than it had been in the past. At the same time the significant changes in the structure of manufacturing in the Veneto, which began in the seventies, explain how workers move from bad to good jobs in a sector-ladder sequence. Workers in bad jobs search for employment in jobs with brighter prospects: good job vacancies are generally matched by employed job seekers, whereas firms in the declining sectors hire mainly unemployed workers. 
Appendix. Churning: various definitions.

Engagements measure new hires. Separations measure terminated contracts, i.e. quits and layoffs. Both measures are defined in continuous time. Worker flow is defined as the total number of accessions to a job or separations from a job in the economy in a definite time interval.

Job flow refers to gross changes of positions and not to changes in employment contracts. It is measured by the sum of job creations and destructions at the establishment level in a definite time interval. A job created means the addition of an extra employee to the stock of workers; a job destroyed means a unit reduction in employment, both measured at the establishment level. Their sum, in absolute terms, is the magnitude of the job flow.

The difference between accessions and separations or between creations and destructions is a measure of the net stock growth. Although in many contemporary economic systems the increase in employment is negligible, this is the result of the creation of many new jobs and of the parallel process of destruction.

Worker flows have two components: those that are an immediate consequence of job creation and destruction and those that are in excess of these flows. The second component is computed as a residue and is referred to as excess reallocation flow or churning. Excess reallocation is defined in different ways. The general definition is based on replaced quits or contemporaneous hirings and firings: in both cases churning expresses the re-evaluation of a job match, initiated either by the employee or by the employer. The word reallocation means that the employer or the employee revises their past decisions or reallocates, while remaining in the same state. The worker moves to a different employer but remains employed. The employer keeps the same employment level but reshapes his firm's skill mix through parallel hiring and firing (Burgess et al., 2000, p.79).

Under very restrictive assumptions this definition is identical to the E-to-E definition used in the paper

A numerical example illustrates the differences between the two previous definitions. Assume an economy, where employment increases by 100 employees, and this is achieved by 150 hires and 50 separations, i.e. 100 new jobs are created. Assume that 50 hires and 50 separations are E-to-E episodes within the same set of firms: their sum is the number of reallocation episodes counted twice. Assume all new jobs are in new firms, $a+s=200, c+d=100, a+s-c-d=100=$ churning. Churning is a measure of E-to-E switches, and the two definitions of churning lead to the same result.

Of course out of the $50 \mathrm{E}$-to-E hires, 50 hires can be placed in increasing firms and the 50 separations in decreasing firms. In such a case $a+s=200, c+d=200, a+s-c$ $-d=0$. No excess reallocation exists, as every association and every separation has its counterpart in a creation and in a destruction. Churning computed as the difference between TT and GJT is zero, but E-to-E switches stay at 100.

A slightly more complex example underlines the ambiguous nature of the definition of churning as the difference between TT and GJT. Go back to the previous example: 150 hires and 50 separations, 100 new jobs created. Assume 150 associations due to hiring from unemployment (U-to-E) and 50 separations due to retirements (out of the labour force: E-to-O). Assume that the same firm hires from the 
unemployed to replace the retirements and keeps the same size. $a+s=200, c+d=$ $100, \mathrm{a}+\mathrm{s}-\mathrm{c}-\mathrm{d}=100=$ churning. But E-to-E episodes are zero because of 200 workers' transfers (U-to-E and E-to-O). These episodes might be more properly labelled allocation episodes as workers change their previous status, from unemployment to employment and from employment to retirement without reallocating at all (in E-U every association or separation counts as 1 allocation episode. In E-E a single association and a single separation counts as 1 reallocation episode).

More formally, let $p_{t}\left(e_{t}\right)$ be the probability of hiring from the pool of active employees. Following Contini and Revelli (1997) for the infinite time horizon, at the beginning of $t$, the sum of the vacancies created $V_{t}$ is the sum of the elements of a geometric series of ratio $p_{t}\left(e_{t}\right)$. Assume that, at time $t, v_{t}$ vacancies open up. The number of jobs filled by active workers is $v_{t} p_{t}\left(e_{t}\right)$, the number of further vacancies filled by already active workers is $v_{t} p_{t}\left(e_{t}\right) p_{t}\left(e_{t}\right)=v_{t} p_{t}^{2}\left(e_{t}\right)$ and so on. The sum of all successive vacancies is

$\mathrm{V}_{t}=v_{t} p_{t}\left(e_{t}\right)+v_{t} p_{t}^{2}\left(e_{t}\right)+\ldots+v_{t} p_{t}^{n}\left(e_{t}\right)+\ldots=v_{t} p_{t}\left(e_{t}\right) \sum_{i=0}^{\infty} p_{t}^{i}\left(e_{t}\right)=v_{t} p_{t}\left(e_{t}\right) \frac{1}{1-p_{t}\left(e_{t}\right)}$

The average length of the chain $\mathrm{L}_{t}$ is computed as the ratio between the number of various transitions $\mathrm{V}_{\mathrm{t}}$ (chain rings) and the total number of the starting episodes of the chains, $v_{t} p_{t}\left(e_{t}\right)$, (chain seeds).

$\mathrm{L}_{\mathrm{t}}=\frac{1}{1-\mathrm{p}_{\mathrm{t}}\left(\mathrm{e}_{\mathrm{t}}\right)}$

$\mathrm{v}_{\mathrm{t}}$, the first step vacancy, approximated by Contini and Revelli (1997) by $\mathrm{c}_{t}$ (creation).

In a stationary world the sum of all the vacancies is equal to the ratio between TT and GJT. Engagements are the sum of the creations plus engagements due to the reallocation process, i.e..

$e_{t}=V_{t}+c_{t}=\frac{c_{t}}{1-p_{t}\left(e_{t}\right)}$

while separations are equal to destructions $\left(\mathrm{d}_{\mathrm{t}}\right)$ plus separations due to the reallocation process, i.e.

$s_{t}=d_{t}+V_{t}=d_{t}+p_{t}\left(e_{t}\right) \frac{c_{t}}{1-p_{t}\left(e_{t}\right)}$

Taking into account that in the stationary state, $\mathrm{c}_{\mathrm{t}}=\mathrm{d}_{\mathrm{t}}$ and $\mathrm{e}_{\mathrm{t}}=\mathrm{s}_{\mathrm{t}}$, and

substituting in (3) $e_{t}+s_{t}=\frac{c_{t}}{1-p_{t}\left(e_{t}\right)}+\frac{d_{t}}{1-p_{t}\left(e_{t}\right)}$. 


$$
\text { Rearranging } \frac{\mathrm{TT}_{t}}{\mathrm{GJT}_{\mathrm{t}}}=\frac{1}{1-\mathrm{p}_{\mathrm{t}}\left(\mathrm{e}_{\mathrm{t}}\right)}
$$

Remember the meaning of the ratio between Total turnover and Gross job turnover, $\frac{\mathrm{TT}_{t}}{\mathrm{GJT}_{\mathrm{t}}}=\frac{\left(\mathrm{s}_{\mathrm{t}}+\mathrm{e}_{\mathrm{t}}\right) / \mathrm{TR}_{\mathrm{t}}}{\left(\mathrm{c}_{\mathrm{t}}+\mathrm{d}_{\mathrm{t}}\right) / \mathrm{TR}_{\mathrm{t}}}$.

So churning, defined as the average measure of E-to-E flows - under restrictive assumptions - is easily obtained from computing the ratio between total turnover and gross job turnover.

Let us infringe the stationary state condition. In a labour market with a non-zero balance between entrances and exits, churning, defined as a ratio of TT to GJT, misrepresents the true replacement process.

In a growing economy, let us assume $\mathrm{e}_{\mathrm{t}}-\mathrm{s}_{\mathrm{t}}=\delta_{\mathrm{t}}>0$, from (3) and (5)

$$
\begin{aligned}
& \mathrm{s}_{\mathrm{t}}=\mathrm{d}_{\mathrm{t}}+\mathrm{p}_{\mathrm{t}}\left(\mathrm{e}_{\mathrm{t}}\right) \mathrm{e}_{\mathrm{t}}=\mathrm{d}_{\mathrm{t}}+\mathrm{p}_{\mathrm{t}}\left(\mathrm{e}_{\mathrm{t}}\right)\left(\delta_{\mathrm{t}}+\mathrm{s}_{\mathrm{t}}\right) \Rightarrow \mathrm{s}_{\mathrm{t}}-\mathrm{p}_{\mathrm{t}}\left(\mathrm{e}_{\mathrm{t}}\right) \mathrm{s}_{\mathrm{t}}=\mathrm{d}_{\mathrm{t}}+\mathrm{p}_{\mathrm{t}}\left(\mathrm{e}_{\mathrm{t}}\right) \delta_{\mathrm{t}} \Rightarrow \\
& \Rightarrow \mathrm{s}_{\mathrm{t}}=\frac{\mathrm{d}_{\mathrm{t}}+\mathrm{p}_{\mathrm{t}}\left(\mathrm{e}_{\mathrm{t}}\right) \delta_{\mathrm{t}}}{\left(1-\mathrm{p}_{\mathrm{t}}\left(\mathrm{e}_{\mathrm{t}}\right)\right)}+\mathrm{e}_{\mathrm{t}}-\mathrm{e}_{\mathrm{t}}
\end{aligned}
$$

From (3):

$$
\begin{aligned}
& s_{t}+e_{t}=\frac{d_{t}+p_{t}\left(e_{t}\right) d_{t}}{\left(1-p_{t}\left(e_{t}\right)\right)}+\frac{c_{t}}{\left.\left(1-p_{t}\left(e_{t}\right)\right)\right)} \Rightarrow\left(s_{t}+e_{t}\right)\left(1-p_{t}\left(e_{t}\right)\right)=d_{t}+p_{t}\left(e_{t}\right) d_{t}+c_{t} \Rightarrow \\
& \Rightarrow p_{t}\left(e_{t}\right)=\frac{\left(s_{t}+e_{t}\right)-\left(d_{t}+c_{t}\right)}{\left(s_{t}+e_{t}+d_{t}\right)}=\frac{T T_{t}-G J T_{t}}{T T_{t}+d_{t} / T_{t}}
\end{aligned}
$$

With simple algebra:

$$
\frac{1}{1-\mathrm{p}_{\mathrm{t}}\left(\mathrm{e}_{\mathrm{t}}\right)}=\frac{\mathrm{TT}_{\mathrm{t}}+\delta_{\mathrm{t}} / \mathrm{TR}_{\mathrm{t}}}{\mathrm{GJT}_{\mathrm{t}}+\delta_{\mathrm{t}} / \mathrm{TR}_{\mathrm{t}}}
$$

In a growing (declining) economy gross excess reallocation overvalues (undervalues) the true replacement process, represented by the sum of the successive reallocation waves. In a declining economy gross excess reallocation undervalues the replacement flows $\left(\delta_{t}<0\right)$. In our study area churning overvalues the magnitude of the E-to-E flows by $3-4 \%$ per year, on average, just because of the positive growth rate of the economy.

Remove the assumption that autonomous vacancies (the beginning of the chain) are always the result of job creations. Consider an open position, following a retirement, filled by a new entrant in the labour market, or hiring and separation flows resulting from the firm's personnel policy exploiting specific segments of the labour market (i.e. job on call or seasonal contracts) or taking advantage of specific training-work 
programs (i.e. work and training program - cfl - and apprenticeship): worker flows are larger than job flows but no worker reallocation is implied, according to the common meaning of the word reallocation.

Churning computed as the difference between total and job turnover would include: 1. Workers who quit and are replaced by young workers entering the labour market $(\mathrm{O}-$ to-E) or by unemployed workers (U-to-E): a change of state for both; 2 . Workers who retire (E-to-O) and are replaced by unemployed workers (U-to-E): a change of state for both; 3. Workers who are hired seasonally (O-to-E) and at the end of the season are not replaced (E-to-O), so that the seasonal job is counted neither as creation nor as destruction.

The uncertain definition of job turnover is at the root of many of problems. Job turnover strictly depends on firms' vertical integration and on timing. It does not allow seasonal work - which is in many ways a true creation/destruction process in the economy - to be counted properly, and churning is defined as the difference between total and job turnover. This definition captures E-to-U or E-to-O flows associated with worker reallocation across a given set of jobs (due to people births and deaths), but does not take into account the proper meaning of the word reallocation. Worker demography (new entrances and retirements) shares the same nature of flows due to the demography of firms and should be treated basically according to the same principles.

At the empirical level - according to the longitudinal database we used - the overvaluation of churning due to the inclusion of the abovementioned spurious components amounts to almost $40 \%$. Just take churning computed as the difference between TT and GJT: $4 \%$ of replacements are due to retirements, $14 \%$ to seasonal work and $22 \%$ to new entrances into the labour market. The inclusion of such a huge number of improper candidates in the churning index leads to blurred results.

\section{References}

Akerloff George A., Andrew K. Rose and Janet L. Yellen, 1988. Job Switching and Job Satisfaction in the U.S. Labour Market, Brookings Papers on Economic Activity, 2, 496-594.

Anastasia Bruno, Maurizio Gambuzza and Maurizio Rasera, 2000. La diffusione dei contratti a tempo determinato: il caso veneto. In Agenzia per l'impiego (a cura di). Solo una grande giostra? Franco Angeli: Milano, 61-188.

Bingley Paul, Tor Eriksson, Axel Werwatz, Niels Westergård Nielsen, 1999. Beyond "Manucentrism". Some Fresh Facts About Job and Workers Flows, mimeo.

Blanchard Olivier J. and Peter A. Diamond, 1989. The Beveridge curve. Brookings papers Econ. Act. 0:1:1-76.

Boeri Tito, 1996. Is job turnover countercyclical? Journal of labour economics, 14, 603-625.

Burda Michael C. and Charles Wyplosz, 1994. Gross Worker and Job Flows in Europe. European Economic Review, 38.6:1278-315.

Burgess Simon, Julia Lane and David Stevens, 2000. Job Flows, Worker Flows and Churning. Journal of Labour Economics, 18, 473-502. 
Burgess Simon, Julia Lane and David Stevens, 2001. Churning dynamics: an analysis of hires and separations at the employer level. Labour Economics, 8, 11-14

Contini Bruno and Riccardo Revelli, 1988. Job creation and Labour Mobility: The Vacancy Chain Model and some Empirical Findings. Università di Torino WP

Contini Bruno and Riccardo Revelli, 1997. Gross Flows vs. net Flows in the Labour Market: What is there to be learned? Labour Economics, 4, 245-263.

Contini Bruno and Claudio Malpede, 2000. Gross Flows and Mobility: Where do We Stand? mimeo. Bressanone.

Davis Steven J., John C. Haltiwanger and Scott Schuh, 1996. Job Creation and Destruction, Cambridge: MIT.

Davis Steven J., John C. Haltiwanger, 1999. Gross Job Flows. In: Ashenfelter O. and D. Card (Eds.). Handbook of Labour Economics. v.3 Amsterdam: North Holland.

Krause Michael U., and Thomas A. Lubik, 2004. On-the-Job Search and the Cyclical Dynamics of the Labour Market, September.

Leonard Jonathan, S. 1987, In the Wrong Place at the Wrong Time. In Lang K. and Leonard J. S. (eds.) Unemployment and the Structure of the Labour Market, New York: Basil Blackwell.

Leonard Jonathan, S. and Marc Van Audenrode, 2000, A Difference in Degree: Unemployment Despite Turnover in the Belgian Labour Market. Mimeo.

Nagypál Eva, 2004, Worker Reallocation over the Business Cycle: The Importance of Job-to-Job Transitions, July 27.

Nagypál Eva, 2005a, Amplification of Productive Shocks: Why Don't Vacancies Like to Hire the Unemployed? July.

Nagypál Eva, 2005b, On the Extent of Job-to-Job Transitions? September.

Occari Fabio and Serafino Pitingaro, 1997, Demografia di impresa e mobilità del lavoro:una stima della componente spuria sulla base degli archivi Inps. WP CNR, Occupazione e livelli di attività in Italia.

Occari Fabio and Serafino Pitingaro, 1998, Flussi di lavoratori e di posti di lavoro; un diverso approccio alle misure del turnover occupazionale. Economia e Società Regionale, 4, 13-37.

Occari Fabio, Giuseppe Tattara and Mario Volpe, 1997, Occupazione, mobilità e componente femminile nel mercato del lavoro: i lavoratori dipendenti a Treviso e Vicenza. In Regione del Veneto, Il mercato del lavoro nel Veneto. Milano: Franco Angeli, 460-488.

Mortensen Dale T. and Christopher A. Pissarides, 1994. Job creation and job destruction in the theory of unemployment. Review of economic studies, 61(3), pp. $397-415$.

Petrognolo Barbara and Christopher Pissarides, 2001. Looking into the Black Box: A survey of the Matching Function. Journal of Economic Literature. (39).2:390-431.

Pissarides Christopher, 1994. Search Unemployment with on the Job Search. Rev. Econ. Studies. 61.3:457-475. 
Pissarides Christopher, 2001. Equilibrium unemployment theory. 2nd ed. Cambridge MA, MIT Press.

Poster 2004. Indagine sulla mobilità dei lavoratori in tre distretti della provinvia di Treviso. Camera di Commercio di Treviso.

Rapiti Fabio, 1998. La misurazione e il significato del turnover occupazionale e i problemi di confrontabilità delle statistiche. Quaderni di ricerca Istat, 3.

Schettkat Ronald, 1992. The Labour Market Dynamics of Economics Restructuring: The United States and Germany in Transition. New York: Praeger Publishers.

Schettkat Ronald, 1996a. Flow in Labour Markets: Concepts and International Comparative Results, in R. Schettkat (ed.), The Flow Analysis of Labour Market, London: Routledge.

Schettkat Ronald, 1996b. Labour Markets Dynamics in Germany, in R. Schettkat (ed.), The Flow Analysis of Labour Market, London: Routledge.

Schettkat Ronald, 1996c. The Flow Approach to Labour Market Analysis: Introduction, in R. Schettkat (ed.), The Flow Analysis of Labour Market, London: Routledge.

Shiner Robert, 2003. The Cyclical Behaviour of Labour Markets, WP. University of Chicago and NBER, Sept. 17.

Shiner Robert, 2005. The Cyclicality of Hires, Separations and Job-to-Job Transitions, Federal Reserve Bank of St. Louis Review, July-August.

Revelli Riccardo, 1995. Potenzialità degli archivi Inps ai fini della stima degli aggregati dei conti economici territoriali. Quaderni di ricerca Istat. Nuova serie.1

Tattara Giuseppe and Mario Volpe, 2001. I distretti industriali: definizioni e storia, in G. Tattara (a cura di), Il piccolo che nasce dal grande. Le molteplici facce dei distretti industriali veneti. FrancoAngeli: Milano, 9-77. 